\title{
Wilantari, dkk.
}

DOI : https://doi.org/10.24843/JFU.2019.v08.i02.p04

pISSN: 2301-7716; eISSN: 2622-4607

Jurnal Farmasi Udayana, Vol 8, No 2, Tahun 2019, 78-89

\section{Aktivitas Penyembuhan Luka Insisi dari Salep Daun Binahong (Anredera scandens (L.) Moq.)}

\author{
Wilantari, P.D. ${ }^{1 *}$, Santika, A. A. G. J. ${ }^{1}$, Buana, K. D. M. ${ }^{1}$, Samirana, P. O. ${ }^{1}$, Sudimartini, L.M. ${ }^{2}$, Semadi, \\ W.J $J^{3}$ \\ ${ }^{1}$ Program Studi Farmasi, Fakultas Matematika dan Ilmu Pengetahuan Alam, Universitas Udayana, \\ Jalan Kampus Unud, Jimbaran, 80364 \\ ${ }^{2}$ Departemen Klinik Veteriner, Fakultas Kedokteran Hewan, Universitas Udayana \\ ${ }^{3}$ Departemen Patologi Anatomi Fakultas Kedokteran Universitas Udayana \\ *Corresponding author e-mail: dessywilantari@gmail.com
}

Riwayat artikel: Dikirim: 04-07-2019; Diterima: 10-12-2019, Diterbitkan: 21-01-2020

\begin{abstract}
ABSTRAK
Luka insisi adalah luka yang terjadi karena teriris oleh instrumen yang tajam, misalnya luka yang terjadi setelah pembedahan atau operasi. Penelitian ini dilakukan untuk mengetahui aktivitas sediaan salep ekstrak daun A. scandens (L.) Moq. pada penyembuhan luka insisi. Parameter standardisasi ekstrak meliputi kadar air, kadar abu total, kadar abu tidak larut asam, dan kadar flavonoid total. Pengujian aktivitas sediaan salep ekstrak daun $A$. scandens (L.) Moq. dilakukan pada tiga puluh lima ekor tikus betina galur Wistar. Pengamatan dilakukan secara makroskopis pada hari ke-0, 7, 14 dan 21 terhadap adanya eritema, edema, dan keropeng, serta pengamatan mikroskopis pada hari ke-21 melihat adanya infiltrasi sel radang dan pembentukan kolagen. Hasil pengamatan makroskopis menunjukkan adanya penurunan tanda eritema dan edema, namun tidak berbeda bermakna secara statistik pada semua kelompok perlakuan (K2, K3, K4, K5, K6, dan K7) (p>0,05) dan keropeng yang menurun dimulai dari hari ke-7. Berdasarkan hasil yang diperoleh, menunjukkan bahwa pemberian sediaan salep ekstrak daun $A$. scandens (L.) Moq. berpotensi dalam penyembuhan luka insisi yang diamati secara makroskopis.
\end{abstract}

Kata kunci : Luka insisi, A. scandens (L.) Moq., eritema, edema, dan keropeng

\begin{abstract}
The incised wound is a wound that occurred because of being cut by a sharp instrument, such as the wound that occurred after surgery. This study was conducted to determine the preparation activity of $A$. scandens (L.) Moq. leaf extract ointment on incised wound healing. The standardization parameters of the extract include water content, total ash content, acid insoluble ash content, and total flavonoid content. Testing of the preparation activity of $A$. scandens (L.) Moq. leaf extract ointment carried out on thirty-five Wistar strain female rats. The observation carried out macroscopically on 0th, 7th, 14th, and 21st days on the presence of erythema, edema, and scab, also a macroscopic observation on the 21 st day has seen inflammatory cell infiltration and collagen formation. Macroscopic observation showed decrease erythema and edema signs, but did not differ statistically on all groups treatment $(\mathrm{K} 2, \mathrm{~K} 3, \mathrm{~K} 4, \mathrm{~K} 5, \mathrm{~K} 6$, and $\mathrm{K} 7)(\mathrm{p}>0.05)$ and scab which decreased start from the 7th day. Based on the result obtained, it was shown that administration of $A$. scandens (L.) Moq.leaf extract ointment has the potential to heal the incised wound which was observed macroscopically.
\end{abstract}

Keywords : Incision wounds, A. scandens (L.) Moq., Erythema, Edema, and Scab

\section{PENDAHULUAN}

Luka merupakan kerusakan integritas jaringan tubuh atau hilangnya kesatuan anatomi jaringan yang diakibatkan oleh sebuah trauma. Berdasarkan kedalaman dan luas luka dibedakan menjadi luka stadium I (superficial); luka stadium II (paratial thickness); luka stadium III; dan luka stadium IV (Bakkara, 2012). Salah satu luka stadium IV yaitu luka insisi yang mana dapat terjadi melalui pembedahan. Berdasarkan data dari World Health Organization (WHO), yang mengungkapkan bahwa jumlah pasien yang menjalani pembedahan dari tahun ke tahun mengalami peningkatan yang signifikan. Tahun 2011 tercatat 140 juta pasien di seluruh rumah sakit di dunia, sedangkan pada tahun 2012 mengalami peningkatan sebesar 148 juta jiwa (Darmawan dan Rihiantoro, 2017). 


\section{Wilantari, dkk.}

DOI : https://doi.org/10.24843/JFU.2019.v08.i02.p04

pISSN: 2301-7716; eISSN: 2622-4607

Jurnal Farmasi Udayana, Vol 8, No 2, Tahun 2019, 78-89

Luka insisi merupakan luka yang ditimbulkan karena teriris oleh instrumen yang tajam, seperti luka yang terjadi setelah pembedahan atau operasi (Brunner dan Suddarth, 2002). Luka insisi dapat dikelompokkan menjadi luka kronis jika mengalami keterlambatan penyembuhan atau menunjukkan tanda-tanda infeksi karena terkontaminasi bakteri. Oleh karena itu, pengobatan luka insisi sangat penting dilakukan. Pengobatan luka insisi umumnya menggunakan obat konvensional seperti antibiotika secara topikal. Penggunaan antibiotik yang tidak sesuai aturan dapat menyebabkan resisten. Oleh karena itu, untuk mengurangi risiko penggunaan antibiotik yang tidak sesuai aturan, diperlukan pengobatan lain yaitu pengobatan komplementer. Menurut WHO (2013) pengobatan komplementer dapat digunakan dari bahan tanaman, mineral, hewan atau kombinasi bahannya yang berpotensi dalam pengobatan.

Binahong memiliki nama spesies Anredera scandens (L.) Moq. yang masuk ke dalam famili Basellaceae. Tanaman A. scandens (L.) Moq. secara ilmiah memiliki aktivitas farmakologis sebagai antibakteri, antiinflamasi (Fitria, 2009; Feybriyanti, 2011). Ekstrak etanol 70\% daun A. scandens (L.) Moq. dilaporkan memiliki aktivitas sebagai antiluka bakar dan antiluka eksisi (Karismawan, 2013; Samirana dkk., 2016). Aktivitas penyembuhan luka eksisi ekstrak etanol $70 \%$ daun A. scandens (L.) Moq. juga dilaporkan melalui pembentukan angiogenesis, peningkatan epitelisasi, fibrogenesis, dan pembentukan kolagen (Ariadi, 2016; Subratha, 2016; dan Ardinata, 2017). Melihat penelitian tersebut, ekstrak etanol $70 \%$ daun A. scandens (L.) Moq. kemungkinan berpotensi memiliki aktivitas dalam penyembuhan luka insisi.

Penelitian dari Ariadi (2016), Subratha (2016), Samirana, dkk. (2016), Ardinata (2017), dan Suarka (2018) mengenai aktivitas ekstrak etanol $70 \%$ daun A. scandens (L.) Moq. dalam penyembuhan luka eksisi yang diaplikasikan dalam bentuk sediaan salep. Basis salep yang digunakan merupakan basis hidrokarbon atau lemak yang terdiri dari adeps lanae $15 \%$ dan vaselin album $85 \%$. Basis hidrokarbon digunakan karena dapat memperpanjang kontak bahan obat dengan kulit, sehingga dapat meningkatkan hidrasi pada kulit dan akan mempengaruhi absorpsi perkutan suatu obat (Ansel, 2008; Depkes RI, 2014a). Penelitian Suputri (2018) melaporkan pula bahwa bentuk sediaan yang baik sebagai pembawa ekstrak etanol $70 \%$ daun A. scandens (L.) Moq. adalah bentuk sediaan salep. Hasil pengujiannya dalam suhu kamar $27^{\circ} \mathrm{C}\left( \pm 2^{\circ} \mathrm{C}\right)$ menunjukkan bahwa bentuk sediaan salep yang stabil pada pengujian organoleptis, homogenitas, daya sebar, daya lekat serta viskositas, sehingga dalam penelitian ini digunakan bentuk sediaan salep sebagai pembawa ekstrak etanol 70\% daun $A$. scandens (L.) Moq.

Berdasarkan latar belakang tersebut, adapun tujuan dari penelitian ini adalah untuk mengetahui aktivitas sediaan salep daun $A$. scandens (L.) Moq. secara dermal pada penyembuhan luka insisi yang diamati secara makroskopis.

\section{METODE PENELITIAN Alat dan Bahan}

Alat-alat yang digunakan yaitu toples kaca, blender, mortir, stamper, sudip, cawan porselen, timbangan hewan, sendok tanduk, pisau, oven, alat gelas, timbangan analitik, pisau escal, pinset, bak plastik, kawat penutup, pencukur rambut, spidol permanen, alat-alat bedah, dan jangka sorong. Sedangkan bahan-bahan yang digunakan yaitu serbuk daun $A$. scandens (L.) Moq., etanol $70 \%$, adeps lanae, vaselin album, etanol $96 \%$, akuades, $\mathrm{HCl} 37 \%$, rutin, aluminium klorida, natrium asetat, kertas saring bebas abu (WhatmanTM), $\mathrm{NaCl} 0,9 \%$, salep Gentamicin $0,1 \%$, ketamin, catgut chromic, silk, underpad, silk black, gillete, betadine, cefotaxim.

\section{Metode Penelitian \\ Pengumpulan Bahan dan Penyiapan Serbuk Daun A. scandens (L.) Moq}

Determinasi tanaman Anredera scandens (L.) Moq. diperoleh dari PT Balai Konservasi Tumbuhan Kebun Raya "Eka Karya" Bali - LIPI. Pembuatan serbuk daun Anredera scandens (L.) Moq. meliputi proses pengeringan, pengecilan ukuran partikel, dan penetapan susut pengeringan dengan menggunakan metode gravimetri.

\section{Preparasi Ekstrak Daun A. scandens (L.) Moq.}

Serbuk daun $A$. scandens (L.) Moq. kering ditimbang sebanyak $1000 \mathrm{~g}$, kemudian dimaserasi dengan pelarut etanol $70 \%$ sebanyak 10 liter selama \pm 24 jam dengan dilakukan pengadukan sesekali pada 6 jam pertama. Ketika proses telah 


\section{Wilantari, dkk.}

DOI : https://doi.org/10.24843/JFU.2019.v08.i02.p04

pISSN: 2301-7716; eISSN: 2622-4607

Jurnal Farmasi Udayana, Vol 8, No 2, Tahun 2019, 78-89

selesai dilakukan penyaringan. Residu diremaserasi dengan cara yang sama dengan pengulangan 2 kali. Maserat ditampung menjadi satu dan diuapkan dengan Rotary evaporator pada suhu $68^{\circ} \mathrm{C}$ sampai diperoleh ekstrak kental.

\section{Standardisasi Ekstrak Etanol $70 \%$ Daun $A$. scandens (L.) Moq.}

Standardisasi dilakukan di Laboratorium Toksikologi Forensik, Lembaga Forensik Sains dan Kriminologi Universitas Udayana. Standardisasi ekstrak daun A. scandens (L.) Moq. meliputi penetapan kadar air, penetapan kadar abu total, penetapan kadar abu tidak larut asam, dan penetapan kadar flavonoid total.

\section{Pembuatan salep ekstrak etanol daun $A$. scandens (L.) Moq.}

Salep dibuat dengan basis berlemak yaitu adeps lanae dan vaselin album, dengan formula standar adeps lanae $15 \%$ dan vaselin album $85 \%$. Pertama, adeps lanae dan vaselin album dipanaskan pada wadah yang terpisah agar melebur di atas air yang mendidih. Kemudian adeps lanae dan vaselin album dicampur pada mortir yang berisi air panas pada suhu $50^{\circ} \mathrm{C}$. Setelah campuran tersebut diaduk dengan kecepatan konstan hingga homogen terbentuklah basis salep. Sediaan salep yang akan digunakan pada penelitian ini memiliki konsentrasi ekstrak terstandar daun $A$. scandens (L.) Moq. sebanyak $10 \%, 20 \%$ dan $40 \%$.

\section{Uji aktivitas penyembuhan luka insisi dari salep daun A. scandens (L.) Moq.}

Hewan uji yang digunakan yaitu 35 ekor tikus putih betina galur wistar yang berumur 2-3 bulan dengan berat badan antara 200 sampai 300 gram. Tikus yang digunakan adalah tikus sehat secara klinis. Tikus dibagi menjadi 7 kelompok (masing-masing kelompok terdiri dari 5 ekor tikus) yang mendapatkan perlakuan berbeda-beda, namun kondisi setiap kelompok dibuat sama baik dari pemberian makanan, berat badan, maupun jenis kelamin. Sebelum dilakukan pengujian, hewan uji diaklitimasi selama 1 minggu, kemudian tikus dianestesi sebelum pembuatan luka dengan ketamin hidroklorida secara intramuskular dosis 50-100 mg/kgBB (Plumb, 2008). Bulu pada bagian punggung dicukur menggunakan alat pencukur dan area yang akan dibuat luka ditandai. Luka insisi pada bagian punggung sepanjang $2 \mathrm{~cm}$ dengan kedalaman sampai melalui otot sejajar tulang vertebra, berjarak $5 \mathrm{~cm}$ dari telinga menggunakan punch biopsy dan pisau bedah. Selanjutnya diberikan perlakuan pada masingmasing kelompok hewan uji dan diamati pada hari ke-0, 7, 14, dan 21.

Perlakuan yang diberikan meliputi : Kontrol normal (K1) yakni tidak dilakukan perlukaan dan tidak diberikan perlakuan; Kontrol negatif (K2) yakni hanya dilakukan perlukaan dan tidak diberikan perlakuan; Kontrol positif (K3) yakni dilakukan perlukaan dan diberikan Salep Gentamicin 2 x sehari; Uji pembawa (K4) yakni dilakukan perlukaan dan diberikan olesan pembawa salep ekstrak 2 x sehari; Uji ekstrak (K5) yakni Dilakukan perlukaan + diolesan salep ekstrak daun binahong konsentrasi 10\% $2 \mathrm{x}$ sehari; Uji ekstrak (K6) yakni Dilakukan perlukaan dan diolesan salep ekstrak daun binahong konsentrasi 20\% 2 x sehari; Uji ekstrak (K7) yakni Dilakukan perlukaan dan diberikan olesan salep ekstrak terstandar daun binahong konsentrasi $40 \% 2$ x sehari.

\section{Pengamatan makroskopis}

Pengamatan secara makroskopis meliputi pengamatan terhadap kemerahan (eritema), bengkak (edema) dan ada atau tidaknya keropeng yang timbul selama perlakuan 21 hari. Pengamatan keropeng dilakukan dengan melihat ada atau tidaknya serum yang mengering berwarna kuning-hitam. Pengamatan terhadap eritema dilakukan dengan melihat adanya tanda-tanda warna kemerahan pada luka, sedangkan pengamatan edema dilakukan dengan melihat

Tabel 1. Skor nilai eritema dan edema (Kuncari dkk., 2015).

\begin{tabular}{|c|c|c|}
\hline Kriteria & Skor & Keterangan \\
\hline \multirow{5}{*}{$\begin{array}{l}\text { Kemerahan } \\
\text { (Eritema) }\end{array}$} & 0 & Tidak ada eritema \\
\hline & +1 & $\begin{array}{l}\text { Sedikit eritema (hampir } \\
\text { tidak tampak) }\end{array}$ \\
\hline & +2 & $\begin{array}{l}\text { Eritema tampak jelas } \\
(25,1-3 \mathrm{~mm})\end{array}$ \\
\hline & +3 & $\begin{array}{l}\text { Eritema sedang sampai } \\
\text { kuat }(30,1-35 \mathrm{~mm})\end{array}$ \\
\hline & +4 & Eritema parah (ada luka) \\
\hline \multirow{3}{*}{$\begin{array}{l}\text { Bengkak } \\
\text { (Edema) }\end{array}$} & 0 & Tidak ada edema \\
\hline & +1 & $\begin{array}{l}\text { Edema sangat ringan } \\
\text { (hampir tidak terlihat) }\end{array}$ \\
\hline & +2 & $\begin{array}{l}\text { Edema ringan } \quad \text { (jelas } \\
\text { terlihat \& ketebalan }<1 \\
\mathrm{~mm})\end{array}$ \\
\hline
\end{tabular}




\section{Wilantari, dkk.}

DOI : https://doi.org/10.24843/JFU.2019.v08.i02.p04

pISSN: 2301-7716; eISSN: 2622-4607

Jurnal Farmasi Udayana, Vol 8, No 2, Tahun 2019, 78-89

$\begin{array}{ll}\text { +3 } & \text { Edema sedang (ketebalan } \\ & \pm 1 \mathrm{~mm}) \\ +4 & \begin{array}{l}\text { Edema parah (ketebalan }> \\ 1 \mathrm{~mm})\end{array}\end{array}$

adanya tanda-tanda bengkak pada luka. Tandatanda tersebut kemudian diukur menggunakan jangka sorong dan hasil pengukurannya dinilai dengan skor seperti Tabel 1.

\section{HASIL}

\section{Hasil Pengujian Susut Pengeringan Serbuk Daun A. scandens (L.) Moq.}

Serbuk simplisia daun A. scandens (L.) Moq. yang diperoleh memiliki nilai susut pengeringan sebesar 8,048 $\pm 0,109 \% \mathrm{~b} / \mathrm{b}$.

\section{Preparasi Ekstrak Etanol $70 \%$ Daun $A$ scandens (L.) Moq.}

Ekstrak etanol $70 \%$ daun binahong ( $A$. scandens (L.) Moq.) yang diperoleh memiliki rendemen sebesar 22,1037\%.

\section{Hasil Standardisasi Ekstrak Etanol 70\% Daun A. scandens (L.) Moq.}

Standardisasi ekstrak etanol $70 \%$ daun binahong (A. scandens (L.) Moq.) yang diperoleh memiliki kadar air sebesar 3,826 $\pm 0,097 \%$ b/b, kadar abu total sebesar $0,2393 \pm 0,0479 \% \mathrm{~b} / \mathrm{b}$, kadar abu tidak larut asam sebesar 0,0261 \pm $0,0021 \% \mathrm{~b} / \mathrm{b}$, dan kadar flavonoid total sebesar $9,983 \pm 0,090 \% \mathrm{~b} / \mathrm{b}$.

Aktivitas penyembuhan luka insisi dari salep daun A. scandens (L.) Moq.

\section{Pengamatan Makroskopis Eritema}

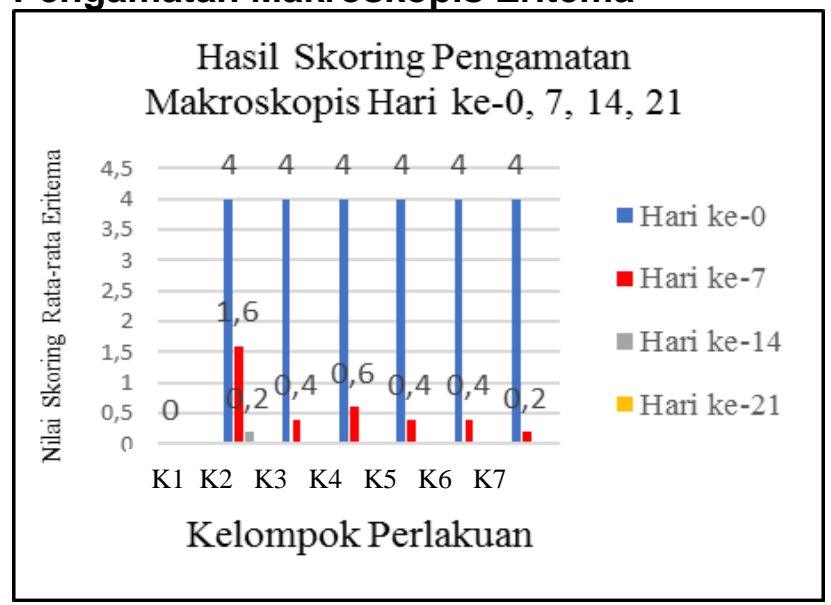

Gambar 1. Diagram Batang Pengamatan Makroskopis Eritema (Hari ke-0, 7, 14, dan 21).

\section{Pengamatan Makroskopis Edema}

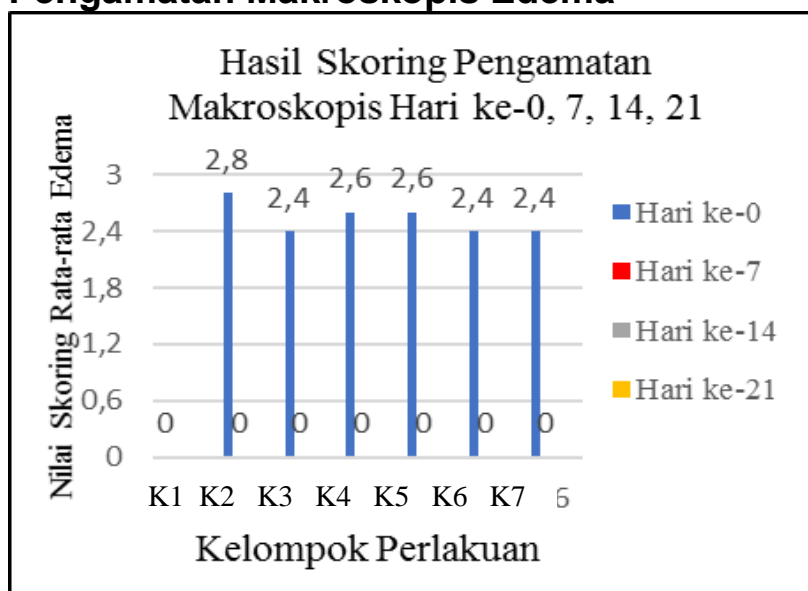

Gambar 2. Diagram Batang Pengamatan Makroskopis Edema (Hari ke-0, 7, 14, dan 21).

\section{Pengamatan Makroskopis Keropeng}

Pada pengamatan hari ke-0 tidak ada diamati adanya keropeng pada masing-masing perlakuan. Pada pengamatan hari ke-7 diamati adanya keropeng pada $\mathrm{K} 2, \mathrm{~K} 3, \mathrm{~K} 4, \mathrm{~K} 5, \mathrm{~K} 6$, dan $\mathrm{K} 7$. Pada pengamatan hari ke-14 menunjukkan adanya keropeng pada K2, K4, dan K5. Pada pengamatan hari ke-21 tidak ditemukan adanya tanda keropeng pada semua kelompok.

\section{PEMBAHASAN}

Uji aktivitas penyembuhan luka insisi daun binahong (A. scandens (L.) Moq.) diawali dengan melakukan determinasi untuk mengetahui kebenaran identitas suatu tanaman, sehingga dapat menghindari kesalahan dalam penelitian. Selanjutnya dilakukan pemilihan dan pengeringan kembali sampel daun $A$. scandens (L.) Moq. untuk memisahkan benda-benda asing seperti bagian tanaman yang tidak diinginkan dan pengotor lain yang masih ada dan tertinggal pada simplisia yang diperoleh (Wahyuni dkk., 2014). Pengayakan serbuk daun A. scandens (L.) Moq. dilakukan untuk memperoleh serbuk halus sehingga rendemen ekstrak yang diperoleh lebih maksimal. Serbuk simplisia daun $A$. scandens (L.) Moq. memperoleh nilai susut pengeringan sebesar 8,048 \pm $0,109 \% \mathrm{~b} / \mathrm{b}$, yang mana nilai ini telah memenuhi 


\section{Wilantari, dkk.}

DOI : https://doi.org/10.24843/JFU.2019.v08.i02.p04

pISSN: 2301-7716; eISSN: 2622-4607

Jurnal Farmasi Udayana, Vol 8, No 2, Tahun 2019, 78-89

syarat pada Farmakope Herbal Indonesia yang menyatakan bahwa nilai susut pengeringan serbuk daun A. scandens (L.) Moq. tidak lebih dari 10\% (Kemenkes RI, 2011).

Pembuatan ekstrak dari serbuk daun $A$. scandens (L.) Moq. menggunakan metode maserasi dan pelarut etanol 70\% (Kementrian Kesehatan RI, 2011). Nilai rendemen yang diperoleh pada proses ekstraksi dalam penelitian ini adalah 22,1037\% Nilai tersebut telah memenuhi syarat nilai rendemen ekstrak serbuk simplisia daun $A$. scandens (L.) Moq. yang ditetapkan dalam Farmakope Herbal Indonesia yaitu tidak kurang dari 11,91\% (Kementrian Kesehatan RI, 2011). Rendemen ekstrak dapat digunakan sebagai acuan jumlah kandungan kimia yang terbawa oleh pelarut, semakin besar presentase rendemen ekstrak yang diperoleh menandakan semakin tinggi kandungan kimia didalamnya (Ahmad dkk., 2016).

Ekstrak yang sudah diperoleh distandardisasi untuk menjamin konsistensi kandungan dan menjamin efikasi dari ekstrak. Standardisasi dilakukan dengan penetapan kadar air, kadar abu total, kadar abu tidak larut asam, dan kadar flavonoid total. Berdasarkan hasil standardisasi yang diperoleh di atas, yang mana semua hasil tersebut sudah sesuai dengan persyaratan yang ditetapkan dalam Farmakope Herbal Indonesia. Ekstrak yang sudah terstandar dibuat menjadi sediaan salep dengan konsentrasi bahan aktif ekstrak etanol $70 \%$ daun $A$. scandens (L.) Moq. sebanyak 10\%, 20\% dan 40\%.

Pengamatan makroskopis dilakukan untuk mengetahui aktivitas penggunaan sediaan uji yang diberikan secara topikal terhadap adanya tanda radang yaitu kemerahan, bengkak dan terbentuknya keropeng pada luka. Pengamatan makroskopis pada hari ke-0 ditemukan adanya eritema dan edema yang cukup parah pada semua kelompok dan belum ditemukan adanya tanda keropeng. Pengamatan hari ke-7 menunjukkan adanya tanda eritema dan keropeng, dan tidak ditemukan adanya edema pada semua kelompok. Tanda eritema pada kelompok K7 terlihat lebih rendah dibandingkan dengan kelompok perlakuan lainnya. Pengamatan hari ke-14 menunjukkan adanya keropeng pada $\mathrm{K} 2, \mathrm{~K} 4$, dan $\mathrm{K} 5$, serta tidak ditemukan eritema dan edema pada semua kelompok. Sedangkan pada pengamatan hari ke21 sudah tidak ditemukan tanda eritema, edema, dan keropeng pada semua kelompok.

Berdasarkan Gambar 1, hasil pengamatan makroskopis hari ke-0 ditemukan eritema pada semua kelompok perlakuan dengan nilai rata-rata 4 dan kelompok normal dengan nilai rata-rata 0 , sedangkan hari ke-7 ditemukan pula eritema pada semua kelompok perlakuan dengan nilai rata-rata paling tinggi pada K2 dan paling rendah pada K7. Pengamatan hari ke-14 ditemukan eritema hanya pada K1, dan pada hari ke-21 tidak ditemukan eritema pada semua kelompok. Begitupula berdasarkan Gambar 2, hasil pengamatan makroskopis pada hari ke-0 ditemukan adanya edema pada semua kelompok perlakuan, sedangkan pada hari ke-7, 14, dan 21 tidak ditemukan edema pada semua kelompok.

Hasil rerata skoring pengamatan eritema dan edema, yang ditunjukkan pada Gambar 1 dan Gambar 2 dianalisis menggunakan program aplikasi SPSS versi 22. Hasil uji non parametrik Kruskal-Wallis pengamatan hari ke- 0 adanya eritema dan edema diperoleh nilai $\mathrm{p}<0,05$ menunjukkan terdapat perbedaan bermakna, sedangkan pengamatan hari ke-7, 14, dan 21 dengan nilai $\mathrm{p}>0,05$ menunjukkan tidak terdapat perbedaan bermakna pada setiap kelompok. Sedangkan hasil uji Mann-Whitney menunjukkan bahwa tidak terdapat perbedaan bermakna pada semua kelompok perlakuan. Berdasarkan hal tersebut diketahui bahwa semua kelompok yang dilukai mengalami eritema dan edema, sedangkan pada kelompok normal tidak mengalami eritema dan edema sehingga menunjukkan perbedaan bermakna pada hasil analisis data antara kelompok normal dengan kelompok perlakuan lainnya. Adanya tanda eritema dan edema ini disebabkan karena terjadinya respon inflamasi akibat terjadinya luka, yang mana pada hari ke-0 merupakan hari terjadinya luka sehingga respon inflamasi akan terjadi hingga terjadi perdarahan akibat proses perlukaan tersebut.

Tanda eritema dan edema merupakan tanda umum adanya respon inflamasi yang diberikan tubuh ketika mengalami luka. Saat terjadi luka tubuh akan merespon dengan vasokonstriksi pembuluh darah untuk menghentikan perdarahan. Keadaan ini diikuti dengan pelepasan mediator 


\section{Wilantari, dkk.}

DOI : https://doi.org/10.24843/JFU.2019.v08.i02.p04

pISSN: 2301-7716; eISSN: 2622-4607

Jurnal Farmasi Udayana, Vol 8, No 2, Tahun 2019, 78-89

inflamasi yang menyebabkan vasodilatasi arteriola dan venula yang mensuplai daerah radang. Sebagai hasil dari reaksi tersebut, maka daerah radang menjadi kongesti yang menyebabkan jaringan berwarna merah dan panas. Bersamaan dengan itu, permeabilitas kapiler akan meningkat, yang menyebabkan cairan berpindah ke jaringan dan menyebabkan kebengkakan dan rasa sakit (Celloti dan Laufer, 2001). Respon tubuh seperti itu disebut respon inflamasi yang biasanya terjadi antara 24-48 jam dan dapat menetap diatas 2 minggu untuk beberapa kasus (Li et al., 2007).

Tanda keropeng merupakan hasil dari reaksi hemostasis tubuh ketika terjadi luka yang menimbulkan perdarahan dan kerusakan jaringan. Hemostasis melibatkan peran trombosit yang berada di tempat terjadinya luka dan mengeluarkan suatu zat berupa asam lemak yang kemudian diubah menjadi tromboksan. Tromboksan dan protrombin bereaksi di dalam darah merangsang trombosit. Kemudian enzimenzim pembantu proses penyembuhan luka mengumpulkan protein yang disebut fibrinogen sehingga terbentuk benang-benang fibrin yang membentuk jaringan tempat keluarnya darah. Benang fibrin tersebut akan mengumpul dan trombosit akan bereaksi dengan udara di luar kemudian mengeras dan membentuk keropeng (Soewolo dkk., 2003). Pembentukan keropeng dapat terjadi pada fase proliferasi atau fase pembentukan sel baru. Fase ini ditandai dengan pembentukan jaringan granulasi yang merupakan kombinasi dari elemen seluler termasuk fibroblas dan sel inflamasi. Fase proliferasi dapat terjadi dari hari ke-4 hingga hari ke-21 setelah terjadinya luka (Tsala et al., 2013).

Pada penelitian ini diperoleh bahwa pemberian salep ekstrak daun $A$. scandens (L.) Moq. berpotensi dalam penyembuhan luka insisi yang diamati secara makroskopis. Hal ini dapat didukung oleh penelitian Feybriyanti (2011) yang melaporkan bahwa ekstrak etanol daun $A$. scandens (L.) Moq. memiliki aktivitas sebagai antiinflamasi. Penelitian Samirana dkk. (2016) melaporkan pula bahwa salep ekstrak daun $A$. scandens (L.) Moq. memiliki aktivitas penyembuhan luka, serta penelitian lain yang melaporkan ekstrak etanol daun A. scandens (L.) Moq. memiliki aktivitas penyembuhan luka eksisi melalui mekanisme angiogenesis, peningkatan epitelisasi, fibrogenesis, dan pembentukan kolagen (Ariadi, 2016; Subratha, 2016; Ardinata, 2017; Suarka, 2018).

\section{KESIMPULAN}

Berdasarkan hasil penelitian yang dilakukan, dapat disimpulkan bahwa salep ekstrak daun $A$. scandens (L.) Moq. memiliki aktivitas penyembuhan luka insisi yang diamati secara makroskopis selama 21 hari, yang menunjukkan adanya penurunan tanda eritema dan edema, namun tidak berbeda bermakna secara statistik pada semua kelompok perlakuan $(\mathrm{p}>0,05)$ dan keropeng yang menurun dimulai dari hari ke-7.

\section{DAFTAR PUSTAKA}

Ahmad, A. R., J. Juwita, S. A. D. Ratulangi, dan A. Malik, 2016, Penetapan Kadar Fenolik dan Flavonoid Tital Ekstrak Metanol Buah dan Daun Patikala (Etlingera Elatior (Jack) Rm Sm) Menggunakan Spektrofotometri Uv-Vis, Pharmacentical Sciences and Reserach (Psr), 2(1): 110.

Ansel, H. C. 2008, Pengantar Bentuk Sediaan Farmasi, Edisi IV, UI Press, Jakarta.

Ardinata, I. P. R. 2017, Profil Kromatografi Kandungan Fitokimia dan Aktivitas Fibrogenesis Ekstrak Etanol Daun Binahong (Anredera scandens (L.) Moq.) pada Penyembuhan Luka Eksisi, Skripsi, Universitas Udayana, Denpasar.

Ariadi, K. A. 2016, Profil Kandungan Kimia dan Aktivitas Angiogenesis dalam Proses Penyembuhan Luka dari Ekstrak Etanol Daun Binahong (Anredera scandens (L.) Moq), Skripsi, Universitas Udayana, Denpasar.

Bakkara, C. J. 2012. Pengaruh Perawatan Luka Bersih Menggunakan Sodium Clorida 0,9\% dan Povidone Iodine 10\% Terhadap Penyembuhan Lukam Post Appendiktomi di RSU Kota Tanjung Pinang Kepulauan Riau. Skripsi. Medan: Universitas Sumatera Utara.

Brunner and Suddarth, 2002, Buku Ajar Keperawatan Medikal Bedah, edisi 8 volume 2, EGC, Jakarta. 


\section{Wilantari, dkk.}

DOI : https://doi.org/10.24843/JFU.2019.v08.i02.p04

pISSN: 2301-7716; eISSN: 2622-4607

Jurnal Farmasi Udayana, Vol 8, No 2, Tahun 2019, 78-89

Celloti, F. And Laufer S., 2001, Inflammation, Healing and Repair Synopsis, J. Phar., 43(5): 2001.

Darmawan, A. A. dan Rihiantoro, T. 2017, Pengetahuan, Sikap dan Perilaku Mobilisasi Dini Pasien Post operasi Laparatomi, Jurnal Keperawatan, XIII:110-117.

Depkes RI, 2014, Farmakpe Indonesia, Edisi V, Departemen Kesehatan Republik Indonesia, Jakarta, Hal. 42.

Feybriyanti, Y. W. 2011. Aktivitas Antiinflamasi Ekstrak N-Heksan, Kloroform, dan Etanol Daun Binahong (Anredera scandens (L.) Moq.) pada Tikus yang Diinduksi Karagenan 1\%. Skripsi. Denpasar: Universitas Udayana.

Fitria, A. 2009. Uji Aktivitas Antibakteri Ekstrak Daun Anredera cordifolia (Tenore) Steen, Anredera scandens (L.) Moq., Basella rubra L. pada Bakteri Gram Positif dan Bakteri Gram Negatif. Skripsi. Denpasar: Universitas Udayana.

Karismawan, P. N. 2013. Profil Kandungan Kimia dan Uji Aktivitas Antiluka Bakar Ekstrak Etanol Daun Binahong (Anredera Scandens (L.) Moq.) Pada Tikus Jantan Galur Sprague Dawley (Skripsi). Denpasar: Universitas Udayana. Hal 40-44, 81.

Kementerian Kesehatan RI. 2011, Farmakope Herbal Indonesia, Edisi I, Departemen Kesehatan Republik Indonesia, Jakarta.

Kuncari, E. S., Iskandarsyah, dan Praptiwi. 2015, Uji Iritasi dan Aktivitas Pertumbuhan Rambut Tikus Putih: Efek Sediaan Gel Apigenin dan Perasan Herba Seledri (Apium graveolens L.), Media Litbangkes, 25: 1522.

Li, J., J. Chen, R. Kirsner, 2007, Pathophysiology of acute wound healing, Clinics in Dermatology. 25: 9-18.
Plumb, D. C., 2008, Veterinary Drug Handbook, Blackwell Publishing.

Samirana, P. O., D. A Swastini, I. D.G. P. Y Subratha, dan K. A. Ariadi. 2016, Uji Aktivitas Penyembuhan Luka Ekstrak Etanol Daun Binahong (Anredera scandens (L.) Moq.) pada Tikus Betina Galur Wistar, Jurnal Farmasi Udayana, 5: 19-23.

Soewolo, dkk., 2003, Fisiologi Manusia, Malang, Universitas Negeri Malang Press.

Suarka, I. P. S. D. 2018. Profil Kromatografi Kandungan Fitokimia dan Aktivitas Pembentukan Kolagen Ekstrak Etanol Daun Binahong (Anredera scandens (L.) Moq.) Pada Penyembuhan Luka Eksisi, Skripsi, Universitas Udayana, Denpasar.

Subratha, I. D. G. P. 2016, Profil Kromatografi Kandungan Fitokimia dan Aktivitas Epitelisasi Ekstrak Daun Binahong (Anredera scandens (L.) Moq.) pada Penyembuhan Luka Eksisi, Skripsi, Universitas Udayana, Denpasar.

Suputri, N. N. K. T. 2018, 'Karakterisasi Kestabilan Fisik Bentuk Sediaan Salep, Gel, Cold Cream dan Krim Ekstrak Etanol 70\% Daun Binahong (Anredera scandens (L.) Moq.), Skripsi, Universitas Udayana, Denpasar.

Tsala, D. E., D. Amadou, and S. Habtemariam. 2013. Natural Wound Healing dan Bioactive Natural Products. Phytopharmacology. 4(3): 532-560.

WHO, 2013, Recommendation on Postnatal Care of The Mother and Newborn. Department of Maternal, Newborn, Child and Adolescent Health, WHO

\section{This work is licensed under a Creative Commons Attribution 4.0 International License}

